\title{
GAMBARAN USIA PADA KEJADIAN COVID-19
}

\author{
Rosyada Elviani ${ }^{1}$ Chairil Anwar ${ }^{2}$ Rico Januar Sitorus ${ }^{3}$ \\ ${ }^{1}$ Program Studi Magister IImu Kesehatan, Fakultas Kesehatan Masyarakat, Universitas Siwijaya \\ 2IImu Kesehatan Masyarakat, Fakultas Kedokteran Universitas Sriwijaya \\ ${ }^{3}$ Program Studi Imu Kesehatan Masyarakat, Fakultas Kesehatan Masyarakat, Universitas Sriwijaya \\ Email : rosyada76@gmail.com
}

\begin{abstract}
Covid-19 is a pandemic that just occurred at the end of 2019 which was caused by SARS CoV2. This must be watched out for because the transmission is fast, has a level of pain that cannot be ignored. To date, there is no proven preventive vaccine and definitive therapy. In several articles, elder was mentioned as a risk factor for Covid19.

The purpose of this study was to determine the age description in the incidence of Covid-19. This is a quantitative study with an observational analytic design with an unmathced case control approach. The data used were secondary data from medical records and surveillance in the isolation room of Dr. M. Hoesin Palembang hospital for the period March 1, 2020 to July 31, 2020, totaling 666 respondents.

Data analysis used univariate to determine the age description in the incidence of Covid-19. The results showed that of the 116 at-risk ages (> 65 years) who were confirmed positive as many as 30 (40.2\%) the remaining 49 (59.8\%) were negative. Meanwhile, of the 550 age groups who were not at risk, 277 (47.4\%) were confirmed positive and the remaining 307 (52.6\%) were negative. In the bivariate analysis, there was no statistically significant relationship between age and Covid-19 with a $p$ value of 0.270 .

The conclusion is that all ages are at risk of being confirmed positive for Covid-19, and productive ages are most at risk for Covid-19 due to high mobility and social activity. This can be prevented by sticking to health protocols.
\end{abstract}

Keyword : Covid-19. Pandemic

\section{ABSTRAK}

Covid-19 adalah Pandemi yang baru terjadi di akhir tahun 2019 yang disebabkan oleh SARS CoV2. Hal ini harus diwaspadai karena transmisi yang cepat, memiliki tingkat kesakitan yang tidak dapat diabaikan. Sampai saat ini, belum ada vaksin pencegahan dan terapi definitif yang belum terbukti. Usia lanjut pada beberapa artikel disebutkan sebagai faktor risiko Covid-19.

Tujuan penelitian ini untuk mengetahui gambaran usia pada kejadian Covid-19. Merupakan penelitian kuantitatif dengan desain analitik observasional dengan pendekatan unmathced case control. Data yang digunakan adalah data sekunder rekam medik dan surveilans ruang isolasi RSUP Dr. M. Hoesin Palembang periode 1 Maret 2020 s/d 31 Juli 2020 yang berjumlah 666 responden.

Analisis data menggunakan univariat untuk mengetahui gambaran usia pada kejadian Covid-19. Hasil penelitian didapatkan bahwa dari 116 usia berisiko (>65 tahun) yang terkonfirmasi positif sebanyak 30 (40,2\%) sisanya 49 $(59,8 \%)$ negatif. Sedangkan dari 550 usia yang tidak berisiko, sebanyak 277 (47,4\%) terkonfirmasi positif dan sisanya 307 (52,6\%) negative. Pada analisis bivariat, tidak ada hubungan yang signifikan secara statistik antara usia dengan Covid-19 dengan $p$ value 0,270.

Kesimpulan adalah semua usia berisiko terkonfirmasi positif Covid-19, dan usia produktif paling berisiko Covid-19 yang dikarenakan mobilitas dan aktifitas sosial yang tinggi. Hal ini dapat dicegah dengan tetap melakukan protokol kesehatan.

Kata Kunci : Covid-19. Pandemi 


\section{PENDAHULUAN}

Pada 31 Desember 2019, China melaporkan kasus pneumonia yang tidak diketahui etiologinya di Kota Wuhan, Provinsi Hubei, Cina. Pada tanggal 7 Januari 2020, dapat diidentifikasi pneumonia yang tidak diketahui etiologinya tersebut sebagai jenis baru disebut Sars-CoV-2 ${ }^{1}$ yang menyebabkan Covid-19. Infeksi Covid-19 sangat sulit dikendalikan sehingga penyebarannya menjadi sangat cepat ${ }^{2}$.

Penambahan jumlah kasus Covid-19 berlangsung cukup cepat dan sudah terjadi penyebaran antar negara sehingga Covid-19 dinyatakan sebagai pandemi oleh $\mathrm{WHO}$ pada 11 Maret 2020. Jumlah kasus yang dikonfirmasi terus meningkat di seluruh dunia. Pada tanggal 16 Agustus 2020, WHO menginformasikan Covid-19 sudah masuk ke 215 negara, 21.026.758 orang terkonfirmasi positif, dengan kematian 755.786 orang (CFR $3,6 \%)^{3}$. Covid19 adalah pandemi yang baru terjadi di awal tahun 2020. Penyakit ini harus diwaspadai karena transmisi yang cepat, memiliki tingkat kesakitan yang tidak dapat diabaikan, dan terapi definitif yang belum terbukti sebagai pengobatan Covid-19. Sampai saat ini, belum ada vaksin pencegahan atau pengobatan yang benar-benar dapat mengobati Covid-194 Maka dari itu perlu diketahui faktor risiko terjadinya Covid-19, sehingga jumlah kasus dapat dicegah dan dikendalikan.

Belum banyak penellitian dan literatur yang meneliti faktor risiko mendapatkan penyakit Covid-19. Pada suatu penelitian di Kuwait menyebutkan bahwa Laki-laki dan umur lebih dari 50 tahun merupakan faktor risiko terjadinya Covid- $19^{4}$. Menurut CDC, delapan dari 10 kematian di AS karena corona virus terjadi pada orang berusia 65 tahun ke atas.
Diperkirakan 6\% hingga 29\% orang berusia 85 dan lebih tua yang menderita Covid-19 akan membutuhkan perawatan intensif ${ }^{5}$. WHO menyebutkan bahwa usia lebih dari 65 tahun merupakan risiko tinggi Covid-16. Berdasarkan data yang dilaporkan ke TESSy dari 24 negara, paling tinggi proporsi Covid-19 pada usia di atas 65 tahun (setidaknya 60 per 100.000) ${ }^{7}$.

Beberapa alasan usia lanjut berisiko terjadi Covid-19 adalah lanjut usia cenderung memiliki masalah kesehatan jangka panjang yang dapat menempatkan mereka pada risiko. Selanjutnya, sistem kekebalan tubuh cenderung melemah dengan bertambahnya usia, membuat orang tua lebih sulit untuk melawan infeksi. Jaringan paru-paru menjadi kurang elastis dari waktu ke waktu, membuat penyakit pernapasan seperti Covid-19 menjadi perhatian khusus bagi orang tua. Peradangan pada orang tua bisa lebih hebat, menyebabkan kerusakan organ ${ }^{8}$.

\section{METODE PENELITIAN}

Penelitian ini merupakan penelitian analitik dengan desain case control. Data yang dalam penelitian ini menggunakan data sekunder dari data penyelidikan epidemiologi dan data rekam medik periode 1 Maret 2020 s/d 31 Juli tahun 2020 yang dirawat inap di ruang isolasi Covid19 RSMH Palembang dengan total jumlah sampel sebanyak 666 responden.Variabel dalam penelitian ini adalah responden yang terkonfirmasi positif sebagai kasus dan terkonfirmasi negatif sebagai kontrol. Kriteria terkonfirmasi positif didapat dari hasil RT-PCR dari swab nasopharing dan oropharing. Analisis data menggunakan analisis univariat dan bivariat untuk menganalisa hubungan antara usia dengan kejadian Covid-1. 


\section{HASIL DAN PEMBAHASAN}

\section{Tabel 1. Distribusi Frekuensi Usia Responden}

\begin{tabular}{ccc} 
Usia & N & Persentase (\%) \\
\hline$>65$ & 83 & 12,5 \\
\hline $56-65$ & 133 & 20,0 \\
\hline $46-55$ & 108 & 16,2 \\
\hline $36-45$ & 102 & 15,3 \\
\hline $26-35$ & 141 & 21,2 \\
\hline $17-25$ & 48 & 7,2 \\
\hline $12-16$ & 12 & 1,8 \\
\hline $6-11$ & 6 & 0,9 \\
\hline$<5$ & 33 & 5,0 \\
\hline Total & 666 & $\mathbf{1 0 0}$ \\
\hline
\end{tabular}

Dari tabel 1 menunjukkan distribusi frekuensi usia responden yand dirawat di ruang isolasi RSMH Palembang. Persentase terbanyak pada rentang usia 26-35 tahun yaitu

Tabel 2. Deskriptif Usia Responden

\begin{tabular}{|l|l|l|l|l|l|l|}
\hline Usia & $N$ & Mean & $S D$ & Med & Min & Max \\
\cline { 2 - 7 } & 666 & 43.58 & 18.59 & 45 & 0 & 90 \\
\hline
\end{tabular}

Dari tabel 2 didapatkan median usia responden 45 tahun dengan mean 43,58 . Hal yang dirawat di ruang isolasi RSMH Palembang ini menunjukkan rata-rata umur responden

Tabel 3 Distribusi Frekuensi usia dan Konfirmasi Positif Covid-19

\begin{tabular}{|l|c|c|c|c|}
\hline \multirow{2}{*}{ Usia } & \multicolumn{2}{|c|}{ Positif } & \multicolumn{2}{c|}{ Negatif } \\
\cline { 2 - 5 } & $n$ & $\%$ & $n$ & $\%$ \\
\hline$>65$ & 35 & 11.3 & 48 & 13.5 \\
\hline $56-65$ & 59 & 19 & 74 & 2.8 \\
\hline $46-55$ & 55 & 17.7 & 53 & 14.9 \\
\hline $36-45$ & 48 & 15.5 & 54 & 15.2 \\
\hline $26-35$ & 74 & 23.9 & 67 & 18.8 \\
\hline $17-25$ & 20 & 6.5 & 28 & 7.9 \\
\hline $12-16$ & 4 & 1.3 & 8 & 2.2 \\
\hline $6-11$ & 1 & 0.3 & 5 & 1.4 \\
\hline$<5$ & 14 & 4.5 & 19 & 23.3 \\
\hline Total & 310 & 46.54 & 356 & 53.46 \\
\hline
\end{tabular}

$21,2 \%$, dan yang paling rendah pada rentang usia 6-11 tahun yaitu 0,9\%. adalah 43 tahun. 
Dari tabel 3 didapatkan bahwa dari total 666 responden yang dirawat di ruang isolasi $\mathrm{RSMH}$ palembang, proporsi terkonfirmasi PCR positif Covid-19 sebanyak $310(46,5 \%)$ dan proporsi dengan hasil PCR
Negatif sebanyak $356 \quad(53,46 \%)$. Pada Responden yang terkonfirmasi positif. Persentase tertinggi pada rentang usia 26-35 tahun ya $(23.9 \%)$, dan paling rendah pada rentang usia 6-11 tahun $(0,3 \%)$.

Tabel 4.Tabulasi Usia berisiko dengan Kejadian Covid-19

\begin{tabular}{ccccccccc}
\hline \multirow{2}{*}{ Usia } & \multicolumn{4}{c}{ Kejadian Covid-19 } & \multirow{2}{*}{ Total } & \multirow{2}{*}{$\begin{array}{c}\text { Nilai P- } \\
\text { value }\end{array}$} \\
\cline { 2 - 6 } & \multicolumn{2}{c}{ Positif } & \multicolumn{2}{c}{ Negatif } & & & \\
\cline { 2 - 6 } & $n$ & $\%$ & $N$ & $\%$ & $N$ & $\%$ & \\
\hline $\begin{array}{l}\text { Usia berisiko } \\
\text { (>65 tahun) }\end{array}$ & 33 & 40,2 & 49 & 59,8 & 116 & 100 & \\
\hline $\begin{array}{l}\text { Usia tidak } \\
\text { berisiko(<65 } \\
\text { tahun) }\end{array}$ & 277 & 47,4 & 307 & 52,6 & 550 & 100 & 0,270 \\
\hline Total & 310 & 46,5 & 356 & 53,5 & 666 & 100 & \\
\hline
\end{tabular}

Pada Tabel 3 didapatkan bahwa dari 116 orang pada usia berisiko, sebanyak 33 $(40,2 \%)$ yang terkonfirmasi positif Covid-19, sedangkan dari 550 orang pada rentang usia yang tidak berisiko ada 277 (47,4\%) terkonfirmasi positif. Dari analisis bivariat didapatkan $p$-value 0,270 , yang berarti bahwa tidak ada hubungan yang signifikan secara statistik antara usia dengan kejadian Covid-19.

Hal yang sama juga dinyatakan dalam sebuah studi bahwa tidak ada perbedaan yang signifikan pada usia ${ }^{8}$. Hal yang berbeda diungkapkan pada studi lainnya bahwa salah satu faktor risiko Covid-19 adalah usia diatas 50 tahun ${ }^{4}$. Beberapa penelitian terkait Covid19 menyatakan orang lanjut usia (lansia) lebih rentan terinfeksi. Penelitian ${ }^{7}$ mengemukakan bahwa lanjut usia dua kali lipat lebih berisiko Covid-19 daripada yang berusia muda. Penelitian ${ }^{8}$ mengemukakan pada orang tua tingkat serangannya lebih tinggi, dengan tertinggi pada kelompok umur 60-69 tahun, dan regresi logistik menunjukkan hubungan yang signifikan secara statistik. Suatu peneitian di
Iran menyebutkan Insiden tertinggi Covid-19 terjadi pada kelompok usia 50-59 tahun, sedangkan angka terendah pada kelompok usia 0-9 tahun $^{9}$

Walaupun demikian, pada penelitian ini responden terbanyak ada pada rentang usia 26-35 tahun yang berjumlah 141 responden dan mean nya 43 tahun, hal ini menunjukkan usia tersebut adalah usia produktif. Pada usia produktif, kemungkinan untuk mendapatkan Covid-19 akan lebih besar, hal ini dikarenakan mobilitas dan aktifitas yang tinggi di luar rumah. Frekuensi dan interaksi sosial kelompok produktif juga lebih tinggi.

Hal yang sama juga diungkapkan oleh CSIS bahwa transmisi infeksi berasal dari kelompok dengan mobilitas yang relatif tinggi, yaitu kelompok usia yang relatif muda ${ }^{10}$. Penyebaran Covid-19 di Italia telah menyerang setiap kelompok usia. Pada awalnya, sebagian besar kasus yang tercatat terjadi di kalangan lansia, tetapi seiring penyebaran virus Corona, orang yang lebih muda terjangkit dalam jumlah yang lebih besar $^{13}$ 


\section{Informasi dari Satgas Covid-19 per 4}

Oktober 2020 mengungkapkan dari total 303.498 kasus Covid-19, 65,4\% di antaranya berusia di bawah 45 tahun. Rinciannya 2,5\% berusia $0-5$ tahun, 7,7\% berusia 6-18 tahun, 24,3\% berusia $19-30$ tahun, dan 30,9\% berusia 31-45 tahun. Dan sebagai informasi dari BPS, $51 \%$ atau mayoritas masyarakat berusia $17-30$ tahun mengabaikan protokol kesehatan karena tak ada sanksi pemerintah ${ }^{11}$. Mempertimbangkan hal tersebut maka perlu dievaluasi pelaksanaan dan sosialisasi Instruksi Presiden Nomor 6 Tahun 2020 tentang Peningkatan Disiplin dan Penegakan Hukum Protokol Kesehatan.

\section{KESIMPULAN}

Hasil penelitian menunjukkan 46,5\% responden terkonfirmasi positif, mean usia responden 43,58, 40,2\%berusia<65 tahun terkondirmasi positif, Tidak terdapat hubungan bermakna antara usia dengan kejadian Covid19. Hal ini berarti bahwa semua usia dapat berisiko untuk terinfeksi Covid-19, dan Usia produktif merupakan usia yang paling berisiko, dikarenakan mobilitas dan aktifitas sosial yang tinggi. Walaupun berisiko, hal ini dapat dicegah dengan tetap melakukan protokol kesehatan (memakai masker, mencuci tangan, melakukan physical dan social distancing serta menghidari keramaian.

\section{REFERENSI}

1. Direktorat Jenderal Pencegahan dan Pengendalian Penyakit.. Pedoman Pencegah dan Pengendalian Corona virus Disease.. 2020;1(Revisi ke-4):1-125.

2. Albitar O, Ballouze R, Ping J, Maisharah S, Ghadzi S. Risk factors for mortality among COVID-19 patients. Diabetes Research Clinical Practise. 2020;166:108293.

3. WHO. Situation Report Coronavirus disease. 2020;(August). Available from: https://www.who.int/docs/default-source/coronaviruse/situation-reports/20200806-covid-19-sitrep199.pdf?sfvrsn=6b9d262d_2

4. Gennaro F Di, Pizzol D, Marotta C, Antunes M, Racalbuto V, Veronese N, et al. Coronavirus Diseases ( COVID-19) Current Status and Future Perspectives: A Narrative Review. Intection Environ Res Public Health. 2020;

5. Almazeedi S, Al-Youha S, Jamal MH, Al-Haddad M, Al-Muhaini A, Al-Ghimlas F, et al. Characteristics, risk factors and outcomes among the first consecutive 1096 patients diagnosed with COVID-19 in Kuwait. EClinicalMedicine. 2020;24.

6. Kim GU, Kim MJ, Ra SH, Lee J, Bae S, Jung J, et al. Clinical characteristics of asymptomatic and symptomatic patients with mild COVID-19. Clinical Microbiology Infection. 2020;26:40-2.

7. Ramananda Ningthoujama DK. WHO statement - "Older people are at highest risk from COVID-19": Should the hypothesis be corroborated or rejected? Elsevier Public Heal Emergencies Collect [Internet]. 2020;(January):19-21. Available from: https://www.ncbi.nlm.nih.gov/pmc/articles/PMC7297172/

8. ECDC. Risk factors and risk groups. Europe Central Disease Prevention Control [Internet]. 2020; Available from: https://www.ecdc.europa.eu/en/covid-19/latest-evidence/epidemiology

9. Maragakis L. Coronavirus and COVID-19: Who is at higher risk? John Hopkins Med [Internet]. 2020; Available from: https://www.hopkinsmedicine.org/health/conditions-anddiseases/coronavirus/coronavirus-and-covid19-who-is-at-higher-risk

10. Stewart C. Daily new coronavirus (COVID-19) cases in Italy since February 2020 (as of December 3, 2020), by date of report. Statista [Internet]. 2020; Available from: 
https://www.statista.com/statistics/1101690/coronavirus-new-cases-development-italy/

11. Davies NG, Klepac P, Liu Y, Prem K, Jit M, Pearson CAB, et al. Age-dependent effects in the transmission and control of COVID-19 epidemics. Natural Medicine. 2020;26(8):1205-11.

12. Burke, Rachel, Sharon Balter, Emily Barnes, Vaughn Barry, Karri Bartlett, Karlyn D Beer, Isaac Benowitz , Holly M Biggs , Hollianne Bruce, Jonathan Bryant-Genevier, Jordan Cates, Kevin Chatham-Stephens , Nora Chea, Howard Chiou, Demian Christia MZ. Enhanced Contact Investigations for Nine Early TravelRelated Cases of SARS-CoV-2 in the United States. 2020;1-26.

13. Kalantari H, Tabrizi AHH, Foroohi F. Determination of COVID-19 prevalence with regards to age range of patients referring to the hospitals located in western Tehran, Iran. Gene Reports [Internet]. 2020;21(August):100910. Available from: https://doi.org/10.1016/j.genrep.2020.100910

14. Vermonte P, Wicaksono TY. Karakteristik dan Persebaran COVID-19 di Indonesia: Temuan Awal. CSIS Comment DMRU-043-ID. 2020;(April):1-12.

15. Ridhoi MA. Mengapa Kaum Muda Lebih Banyak Kena Covid-19? [Internet]. Kata Data.co.id. 2020 [cited 2020 Oct 20]. Available from: https://katadata.co.id/muhammadridhoi/analisisdata/5f7aa8bf3bbd9/mengapa-kaum-muda-lebih-banyakkena-covid-19 